\section{JAN DUIKER: A RIVER SIDE HOTEL IN DOLNÍ ZÁLEZLY NAD LABEM, CZECH REPUBLIC 1929-1930}

JAN DUIKER: UN HOTEL JUNTO AL RÍO EN DOLNÍ ZÁLEZLY NAD LABEM, REPÚBLICA CHECA 1929-1930

Jan Molema
1.Planometric drawing for the competition as

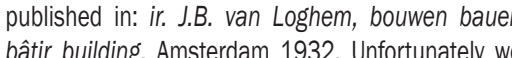
are unable to define the applied colours. The tex in old German gothic letters says: Salesel a(n) der) Elbe. 2. Situation and floor plans as published by Van

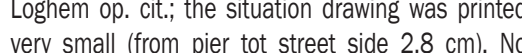
indication of scale was given. NB the two fat lines indicate the row of (linden?) trees on either side of the pot

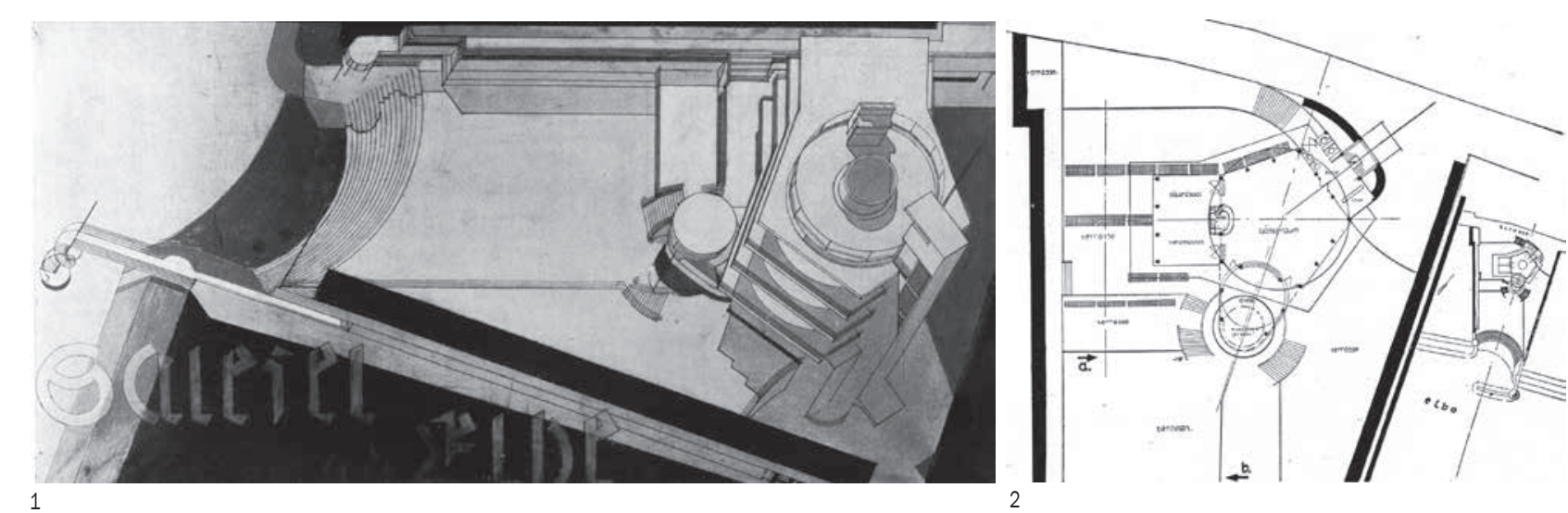

"By no means everything in Duiker is sound in the sence of the mathematical technique, and often not from the viewpoin of centuries long utility. But precisely this makes that his work contains the freshness of the continuously renewing nature". J.B. van Loghem in De Hollandsche revue, jrg 41, 1936, no 8 .

\section{INTRODUCTION}

t was in a very small settlement, Dolní Zálezly (Lower and at an hour drive from Prague, that in 1030 a the north bank of the stream. Therefore a competition was held for which the Dutch avant-gardist Jon Duiker (Den Haag 1800 - Amsterdan 1935) delivered an entry; he would receive the second prize Duiker's brother in arms Johannes van Loghem Bourven bauen bêtir bulling (igures 1 and2) CA. Alberts with $E J$. Jelles, also Delft

but from a post-war generation, added in 1972 three açades in their Duiker 1890-1935.

thing more seemed to have been kept about this compettion in pertaining archives, just as it happened in the case or the better-known Chicago Tibune competwhich Jan Duiker and his colleagues Bernard Bivoet an Jan Gerko Wiebenga ever took part ${ }^{3}$ Still the project is to us one of the most revealing in Duiker's career More so useciuse we mas suppose that in this case no olter designer was involved. We haven't found indications in perpublished in 1932 pert of the drawings of the proectin his

Duiker tod es inpués de la temprana muerte de Jan Duiker, su compatriota Han van Loghem escribio: "De ninguna manera en los siglos. Pero precisamente esto hace que su trabajo contenga a la frescura de la naturaleza que continuamente se reno largo de Ell libro de Van Loshem Bouwen Baven Buidding Batîr (1932) ha sido la única publicación sobre Duiker en vida en el cual, algunas partes, estaban dedicadas a su interesantísimo proyecto para el concurso para un hotel junto al río en Salesel an der Elbe, ahora Dolnin Zálezly nad Labem en la Repúbilica Checa.

En este artículo, he intentado entender el proyecto con el conocimiento que tengo, en general, del trabajo de Jan Duiker, con 10 PALABRAS CLAVE Jan Duiker; concurso; Salesel an der Elbe / (Dolnin Zálesly nad Labem; 1929/1930; modernidad; método de proyecto.

Corresponding author / Persona de contacto: driri.ing.jan.molema@gmail.com. Researcher (retired). Faculty of Architecture. Delft University of Technology, (TU Delft). Nederland.
1. Ir. J.B. (Han) van Loghem: Bouwen bauen bâtir building, Amsterdam, 1932. This is without doubt the bestr report of the Modern Movement in the Netherlands up to that date, with brilliant black and white photographs. C.A. Alberts and EJ.J Jelles, Duiker 1890-1935, in forum, Amsterdam 1972. They obtained this ma

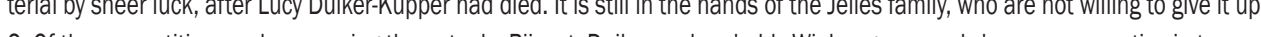

2. Of the compettion, and concerning the entry by Bijvoet, Duiker and probably Wiebenga, we only have a perspective in two variants. Only perspectives seem to have been kept

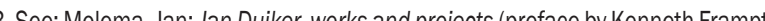

Iorm part of an uncoming book about these three foremen of the Nieuwe Bowwen, (Barcelona: Gustavo Gili, 1991 (English/Spanish). I add, that this article shall 


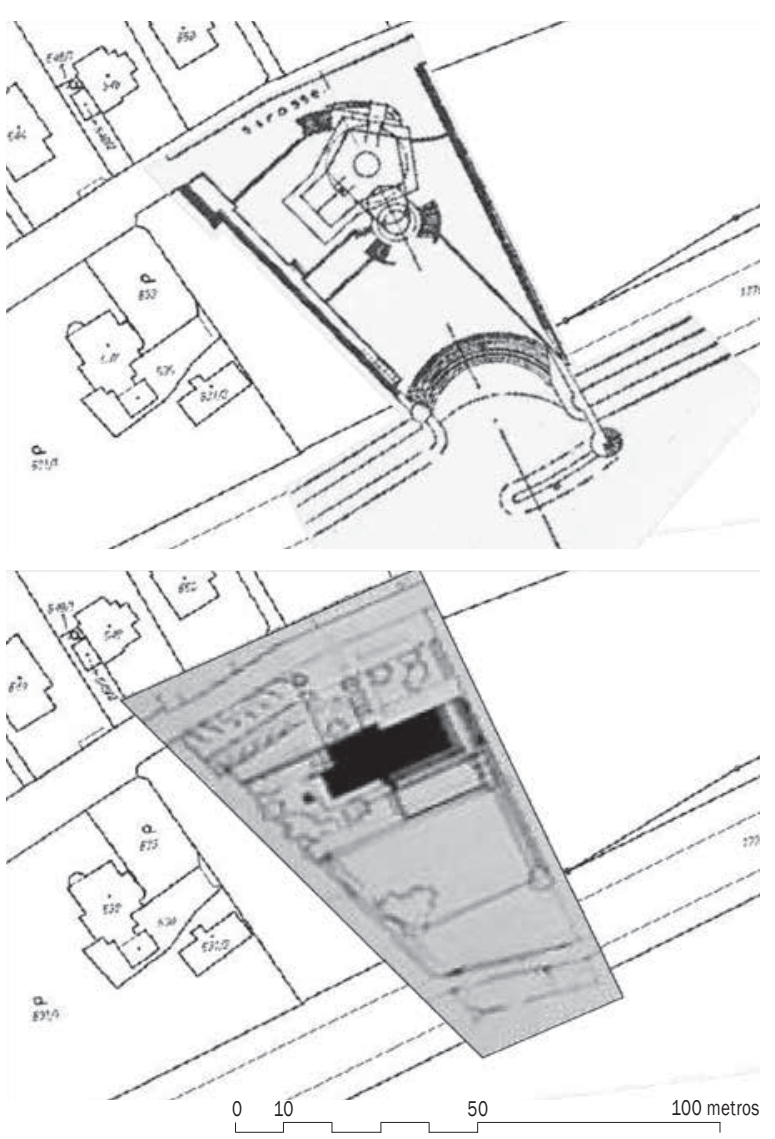

gle with the coastline of the lake. In fact it could have been 'anywhere' as it is nothing special (figure 6).

OTHER PROJECTS AROUND 1930 BY DUIKER (BIJVOET AND WIEBENGA)

At the moment that he had to send his proposal to Aussig. Duiker moved from Daniel Willinkplein to Minervalaan in Berlage Zuid (Amsterdam), to a larger house where (for economic reasons) paying quests could be held. In 1928 they had sold their beautiful convertible Cleveland, as it had become too expensive to have a car ${ }^{31}$ The money for the second prize for the Zálezly entry must have been welcome ${ }^{32}$

Duiker's open-air school was under construction (opening 28 of June), and he was working on the design for its entrance building. The design for an open-air schoo ta

6. Duiker's and Schütte-Lihotsky's site; inserted in a 7. Open Air School Cliostraat Amsterdam Von Loghem, op. cit, as executed (plan 6, 1928). A comparable structure, with its cantlievering and tapering beams and floor slabs and the slimming columns,

Zonneheide had just been presented, but fund raising for the realization was difficult. Late in the summer of 1930 the ephemeral 'tea house' at Zonneheide would open, at the time Duiker (with Biivoet) received the commission for the nurses' roundhouse at Zonnestraali33. Meanwhile Bijvoet was busy in Paris (Maison de Verre), and

FORM, STRUCTURE AND MATERIALS

The pentagon

Why would one choose a pentagon as the elementary form for (a part of) a building? How to trace an angle of 108 degrees when not having the necessary tools? Did Duiker have a drawing machine? Or did he just use a ruler, pear wood triangles (45 and 30/60 degrees) and a compass? Plus a triangle with a swivelling arm, which he could adjust to any desirable angle, in this case $108^{\circ}$ ?35 Duiker's stepson Arthur Hofmans answers that initially 'Jan' had a drawing table with a parallel guide and two loose triangles just as mentioned "The introduction in 1927 or 1928 of a Kühlmann drawing machine (..) was a memorabe happening Jan was very pleased"'s6 So a machine was available to draw the Salesel plan at the turn of the was available to dre

Was it the (form of the) location that led Duiker to the pentagonal form? He clearly did not 'orientate' his building by using the north arrow' instead he put what seems the main axis in the situation drawing shown above on a right angle with the lake border, parallel to the east border line of the plot ${ }^{37}$. But this 'main axis' in the situation drawing is somewhat misleading. It gives bit too much emphasis on the pentagon part of the building.

Duiker used three of the five axis of the pentagon for specific functions. The first with the 'main' axis and the inside/outside dance and music podia, a second

31. Source: Jan Duiker's stepson Arthur Hofmans in his book Hofman, Arthur: Herinneringen aan Jan Duiker. Lelystad/Rotterdam: MEDITekst, 1990. 32. Winning a compettiton can lead to most unpleasant results, as Duiker and Bijvoet had experienced in the compettion for the National Academy for the Arts (Rijksacademie voor Beeldende Kunsten) in Amsterdam. The second prize brings money for the work done and leaves the architect in peace. 3.I It reflects various aspects of the round part of the hotel.

34. We are not sure about the dates of the proposal for a Jamin shop, but its circular plan must be taken into account here. 35. This was 1929, computers were just dreamed of. Later on Duiker must have been able to draw parabolas though, for instance in his Cineac design
36. Hofmans, Arthur, op. cit, p. 55 . See note 31 .

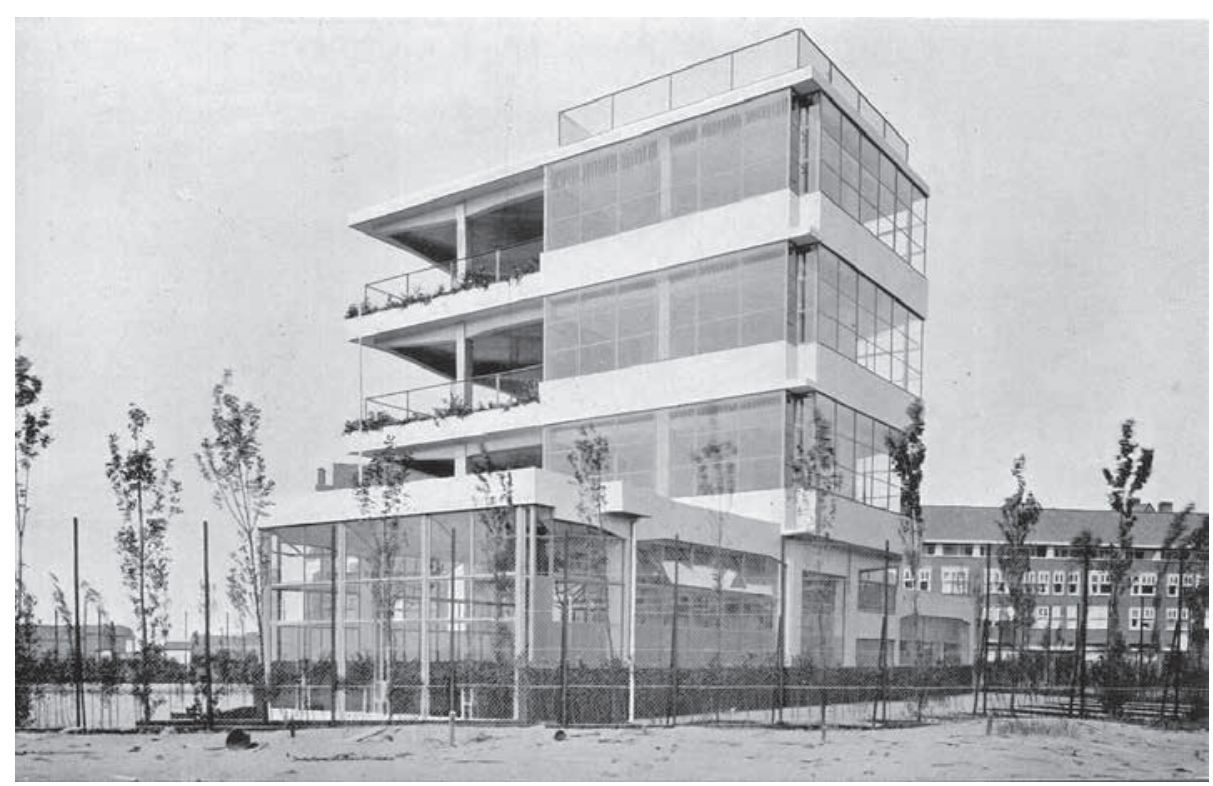

defines the entrance part, a third one a rectangular block with rooms on the higher floors and meeting rooms on the main. The direction of that third axis of the pentagon seems to have defined the western limit of the lot, lying parallel to the side of the rectangle. This looks strange and should be explained.

Margarete Schütte-Lihotsky solves the problem ${ }^{38}$. In her situation drawing the western border of the terrain is exactly as Duiker drew it, including the same protrusion at the street side. Apparently it was a given line, not an invention of Duiker. This explains, I think, sufficiently the pentagon form as resulting from the inclination of the borderlines.

Duiker must have become aware of the fact that there was an inclination angle of precisely $18^{\circ}$, which led to the angle of $(90+18) 108^{\circ}$ of the pentagon $=6 \times 18^{\circ}$. The penlagon contains 5 angles of $108^{\circ}$, which makes 540 .

Circles

est ruineuse, difficile et dangereux: elle parayse $e^{\text {"39. }}$

On the bedroom floors Duiker applied within the pen-

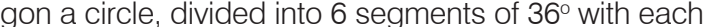
double bedroom. Three segments of $24^{\circ}$ form two singles plus a passage, $72^{\circ}$. Two common bathrooms, a passage and service spaces occupy the rest of the circle, also $72^{\circ}$. A full circle contains $20 \times 18^{\circ}=360^{\circ}$

Why would an architect use a circular surface? Because of its ratio. The proportion between circumference and surface area is optimal. A minimum of façade with a maximum orenclosed area. If we apply a polygon instead, the me lower with fewer sides.

The first circle in BIIvoet and Duiker's œeuvre we find in their refurbishment plan for the Riljswijksche Bank in The Hague (1018). The cylinder would have contained the bicycle shed on the ground floor, and would have soothed composition of this cor School buidings, such as the so-called Schip by Michie de Klerk in Amsterdam Spaarndammerbuurt

The first circle of larger ammension landed "out of the blue' on top of the main building of Zonnestraal (late

37. He could have done the same with a triangular, rectangular or any other regular polygonal figure.

38. Thanks to a quick action of the directorate of the archive of the Universittat tur angewandte Kunst in Vienna, I received copies of the documents from her the Archiv der Univer-

20. A second circular stairwell Bijvoet and Duiker would apply some years later in their famous sardener's house in Aalsmeer (1924‘25). A verry visible volume in brick, souring over the lower floor of the house. It must be understood as the representation of the traditional warehouse chimney, as we can see behind the vase on old pholographs. In no other building or plan in the earlier years of collaboration of the duo we find a single (part of a) circle or other bend form. This would only occur later. Duiker, maybe more than Bjvoet, became fond of circular stairs, in spitie of their somewhat problematic use. The cylinder as an interm. 


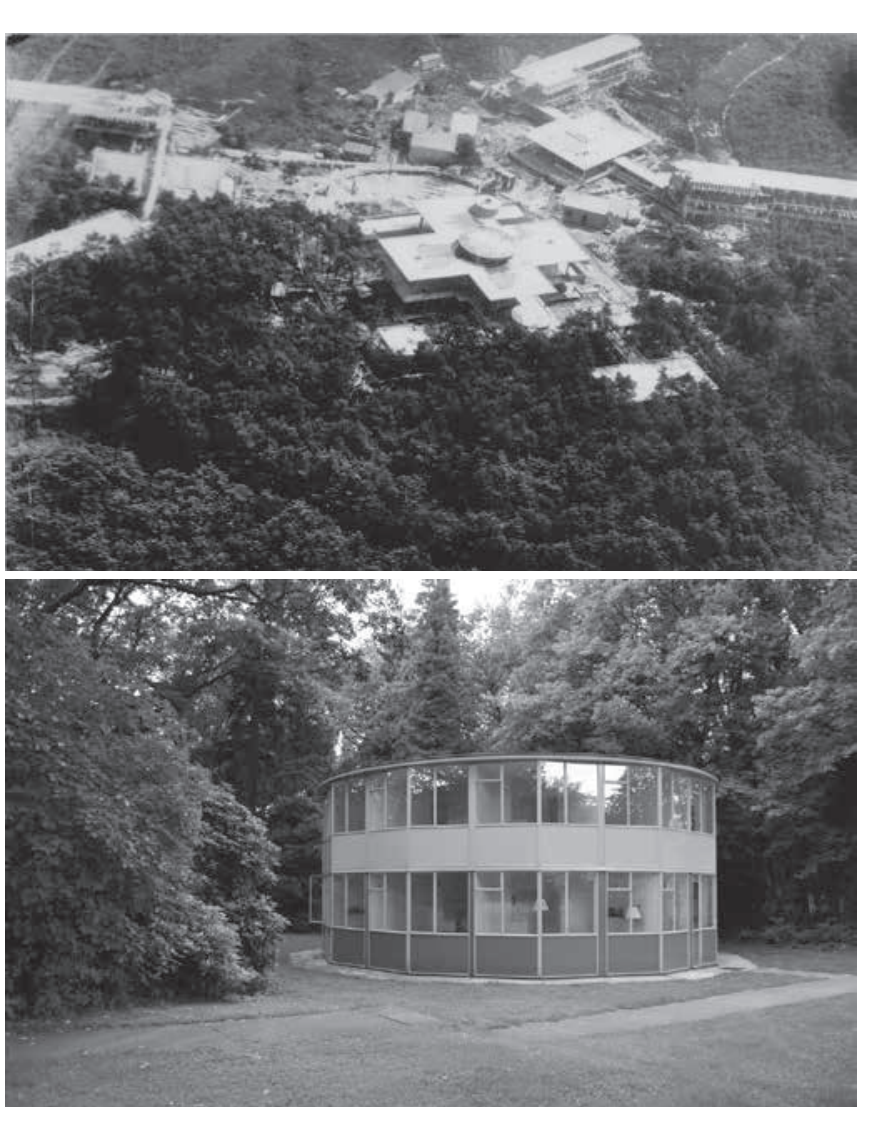

9 . Nurses House Zonnestraal. The structure of this single round building realised by Duiker (and Bijvoet)

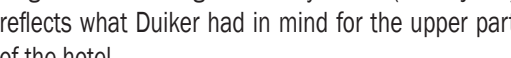

10. League of Nations, preliminary floor plan. The plan, though totally different in scale from it, is very
comparable with the ensemble of workshops and that of an open-air school at Zonnestraal. 11. Drawings on the basis of the available existing material, in which we have tried to make the spatial could: sections and flloor plans.

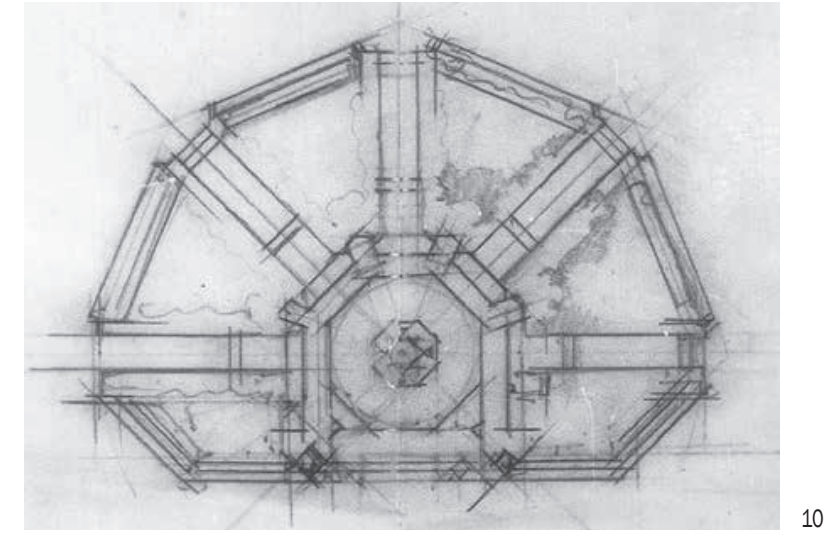

1927). Only during the construction Duiker (and or Bijvoet) concluded that there would be insufficient light inside the cross-formed building and therefore lifted the central part of the roof ${ }^{41}$. Why a circle on a square? I have no idea. Anyway. Zonnestraal also got a discernable cylindrical chimney and water tank ${ }^{42}$ (figure 8).

Polygonals and circles

By 1930 Duiker seems to have become a real fan of nonrectangular buildings. The mentioned circular rooftop of house with eight sides and a round roof This was repla ced by a design with a dodecagon with a circular roof topped with a round skylight. This solely dated design was made in the winter of 1930-1931, but the commission seems to have been given in the summer of $1930^{43} \mathrm{~S}$ So after the Salesel competition. At the same time the design

and model of the open-air school complex near Zonnesraal were ready and presented: a complex of rectangular liting from a central round pond ${ }^{14}$ (figure 9) It was around this time that Duiker started his interest polygonal forms and he was lucky! Salesel gave him an opportunity to investigate its applicability and utility. We must remerty gue of Nations in Geneva (February 1927) the half octogonal and cut hexagnal fom had appeared in phan, while full or Hoogbouw; but we do not find any other pentagon 45 The one in Salesel would be the only one in his career (figure 10).

Whether Duiker was aware of the idea that "the Pythagoreans held the pentacle sacred to Hygeia the Goddess of healing whose name was an anagram in Greek for the elements water earth, spirit fire, and air"46, I do not know,

41.This reason is at least generally accepted, but there is no proof.

42. A circular pond in front of the main building was not executed though.

43. Jan van Zutphen, the goofiather of Zonnestraal proposed it in a meeting of 10 June 1930. (Zonnestraal archive, IISG) But who knows whether Duiker has

not worked on it before? 45. Quite surprising, even the small maid's house at Zonnestraal is very much comparable with the proposed design for the League of Nations complex.
46. http://symboldictionary.net. The Pentagram in Depth.

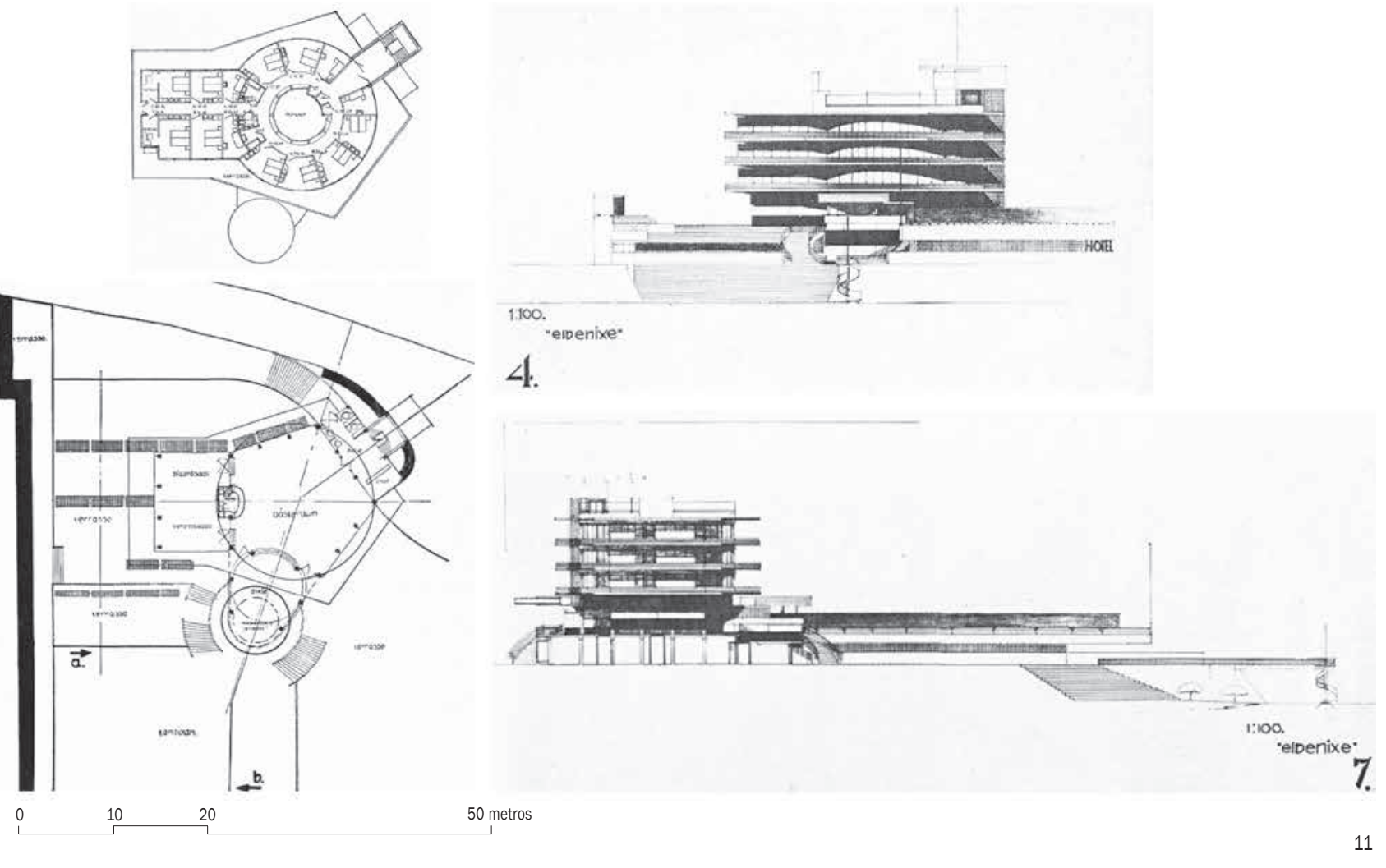

but it seems to be adequate for a beach hotel. If one it is difficult to define the different measures of building wants so, the fact that the central building of Zonnestraal and site. Duiker did the project in a short period. He was received a Greek cross plan may be another indication for very able to do it, but in spite of that we found several symbolism in Duiker's work; the commission had been gi- irregularities in his plans, which makes conclusions risky. ven by the Dutch Red Cross. But this is not what we have We checked the dimensions of the pentagon, the circles researched, as Duiker to my knowledge did not think per and the other 'additions' to the five-sided core. We have definition in symbols when designing. searched proportions between measures, and looked for

PROPORTIONAL SYSTEM

The use of a pentagon may lead us to the idea that Jan Duiker tried to use the Golden Section in his design here When years ago I had the opportunity to show Zonnestraal to the American architect Steven Holl, he exclaimed: it's all Golden Section!' Well, it is not. And the good reason is, that this proportion is not practical in the execution of a work. But where Duiker applies the pentagon, he must have accepted this impracticality for some reason.

DIMENSIONS OF THE PROJECT AND THE SITUATION Neither Duiker nor Schutte-Lihotsky added any measure to their drawings. As we do not have the originals simple dimensions. What we present here is a close approximation, as indicated based on the dimensions of a bed of $190 \mathrm{~cm} \mathrm{long}^{47}$ (figure 11).

THE REMARKABLE USE OF THE GLASS BRICK In 1932 Howard Robertson ${ }^{46}$ wrote about the contemporary Dutch architecture: "On the other hand, there are new materials and tresh possibilities as regards form, which supply the incentive to ploneer and seek for new solution to old problems. For example, the necessity for employing heavy framing round openings, and thick supports in gein, is one which many modern architects would like to eliminate on the score of both utility and effect; yet the use

47. We also took other elements such as doors and stairs into consideration. Here I have to thank Peter Bak for doing the measured drawings included in his

48. Robertson, Howard: Modern Architectural Design, Westminster, 1932, p. 89 etc. Robertson would be one of the architects of the United Nations complex 


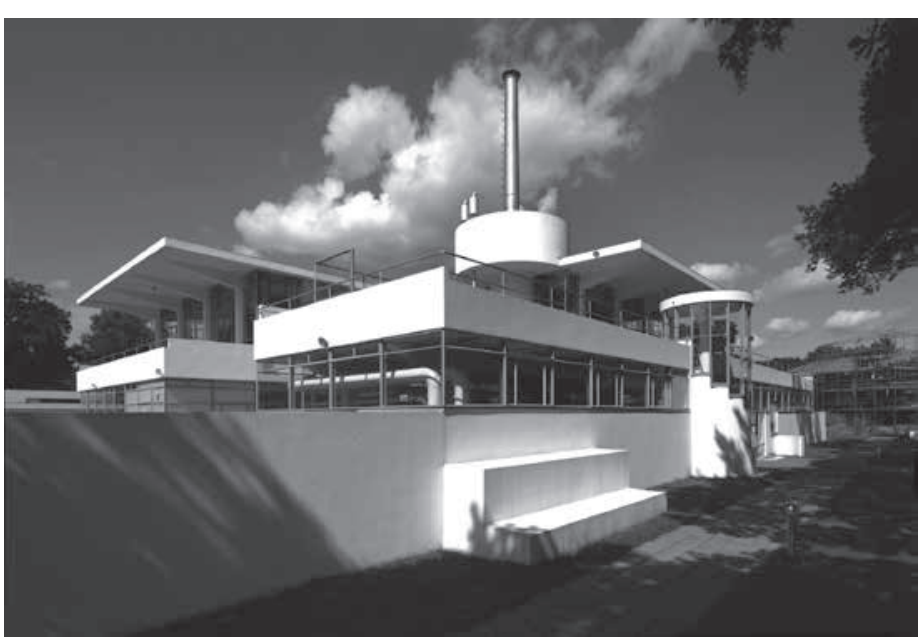

12

13

12. Zonnestraal Main building 13. Ter Meulen Pavilion, vintage photo showing the floor spans $3 \mathrm{~m}$. and $1.50 \mathrm{~m}$. Floors $8-12 \mathrm{~cm}$. thick. 14. Inside of Vocational school Scheveningen.

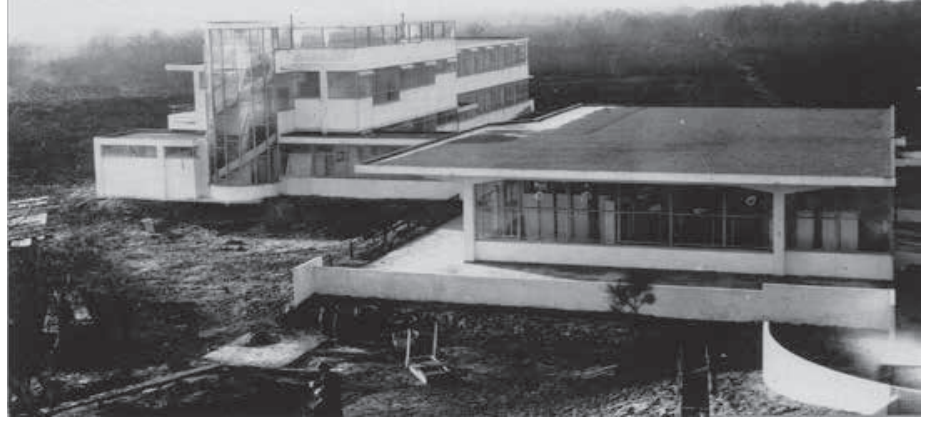

requires a considerable amount both of invention and technical skill. Effects are obtained by some of the more advanced modernists, which at first glance are puzzling. (....)
Glass especially is a most intriguing material for modern work, and requires considerable skill in handiling as well as wide research on the part or manulacturers as to the possible scope of its uses. Such buildings as the Vol Harding at The Hague, designed by J. R. Bulis provide examples of singly in Holland in wite. and in colous an atsed hereaple occuring in the interesting Christion Science Church

at the Hague by that pioneer in modernism, Berlage, who Duiker and Bijvoet knew these buildings very well.

LEAGUE OF NATIONS COMPETITION

Probably the first time Duiker and his fiends proposed the use of glass bricks in large quantities was in their entry for the League of Nations competition, which they delivered early in $1927^{50}$. The sketchy drawings we know of this project are similar to the first ones that Bilvoet made for the Maison de Verre. Ber is now for some days in Geneva to study the plot for the League of Nations Headquarters competition, in which he wants to take part with Jan D(uiker). and Wrebenga "Co Bijvoet-Ezerman wrote this on 26. November 1926, with an addition in the margin on 3 December 1926. Bijvoet wrote on 24 February 1927: "Bu now it is really true (it is always slightly embarrassing to tell real triths) that in the last monhs we have passed a crisis that is really very suitable to blame for everything. You should know hat we have made a design for the League of Nations, no kidding. And what is more: we have been able to deliver it (....)"

MEAGRE BUDGETS AND OTHER BUILDINGS

do not know why Duiker has not made use of this highly transparent material in his most crystalline Dutch works Znen Air School in Amsterdam (plans May 1927-August 1928) pensive maybe? Both were built on a meagre buadget. neveral nó bull designs for the SCALA cinema-cumnightelub at Klene Garman-plantsoen in Amsterdam on the contrary show an abundance (1930-1934). It is in this case modest, Gooiland, exected under Bivivet. There is a pecular

49. Correctly spelled De Volharding and J.W.E. Buijs.
50. This has been unclear for a long time, since no archive of the three contains a set of finished drawings. An interesting side step: Karl Moser, member of the jury, sketched the peculiar rround plan, a hand with spread-out fingers, in his notebook (ETH Zürich, Karl Moser Archive). We find this form more than once in Duiker's work.

51. Here, as in the Maison de Verre we touch once more the problem of authorship. The first plans for the Open Air School wear both names Bijvot and Duiker, the later of six (!) designn the name, signature and or stamp of Duiker. Yet the letering of the last design resembles very much that of the earliest drawing

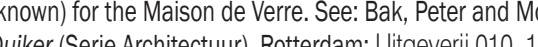

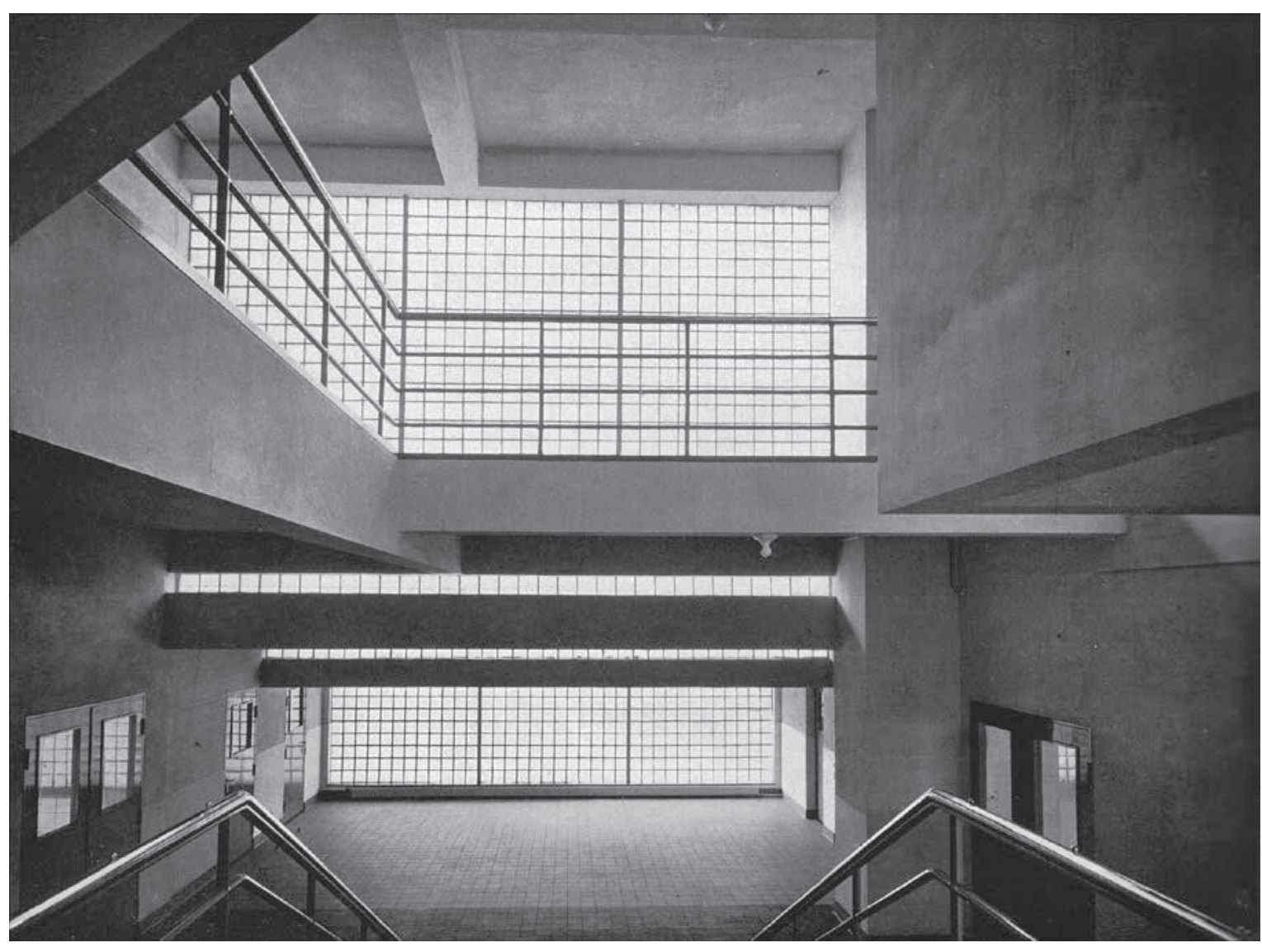

corner in the café behind a stair, where the building touches the neighbouring plot. Glass for illumination was allowed, but no view outwards ${ }^{52}$. In none of all these Dutch works we find panelled glass bricks. Who then,
developed these? My daring idea is: Bijvoet, with the aid of Duiker, while discussing the procedure of the (pre-)fabrication of the façades for Zonnestraal, as mentioned above

Zonnestraal was by all means an experimental project. The façade elements were developed 'n slu' and there is and the Ter Melen pavilin) opent in June (1928, wecan (nis investigation a year before id $1927^{53}$ (figures 12 and 13)

THE THIRD TECHNICAL SCHOOL IN SCHEVENINGEN, THE HAGUE

In June 1928, Duiker and Bijvoet received a new commission for this project ${ }^{54}$. Very different from the first design à la Wright. Already the earliest perspectives show large in corridors and staircase ${ }^{5}$. They show striking likeness again with the sketch Zoetbrood shows us of the front façade of the Maison de Verre ${ }^{56}($ figure 14).

For an explanation of this 'trouvaille' see: Jan Molema, id.

53. For Zonnestraal and its restoration see amon sst other authors Wessel de Jonge in: Meurs, Paul and van Thoor, Marie-Thérèse (eds.): Zonnestraal Sananto rium. The History and Restoration of a Modern Monument, Rotterdam: NAi Publishers 2010.

Berlage's Museum for the Hague. 55. This commission is again an interesting fact in relation to the social background of the architects: the secreteary of the Technical school in The Hague was the father of Jan Duikers brotherin-law. The responsible alderman was Johan Willem Albarda (SDAP), who around 1920 lived next door to the studio of Duiker 56. www.erzed.n 


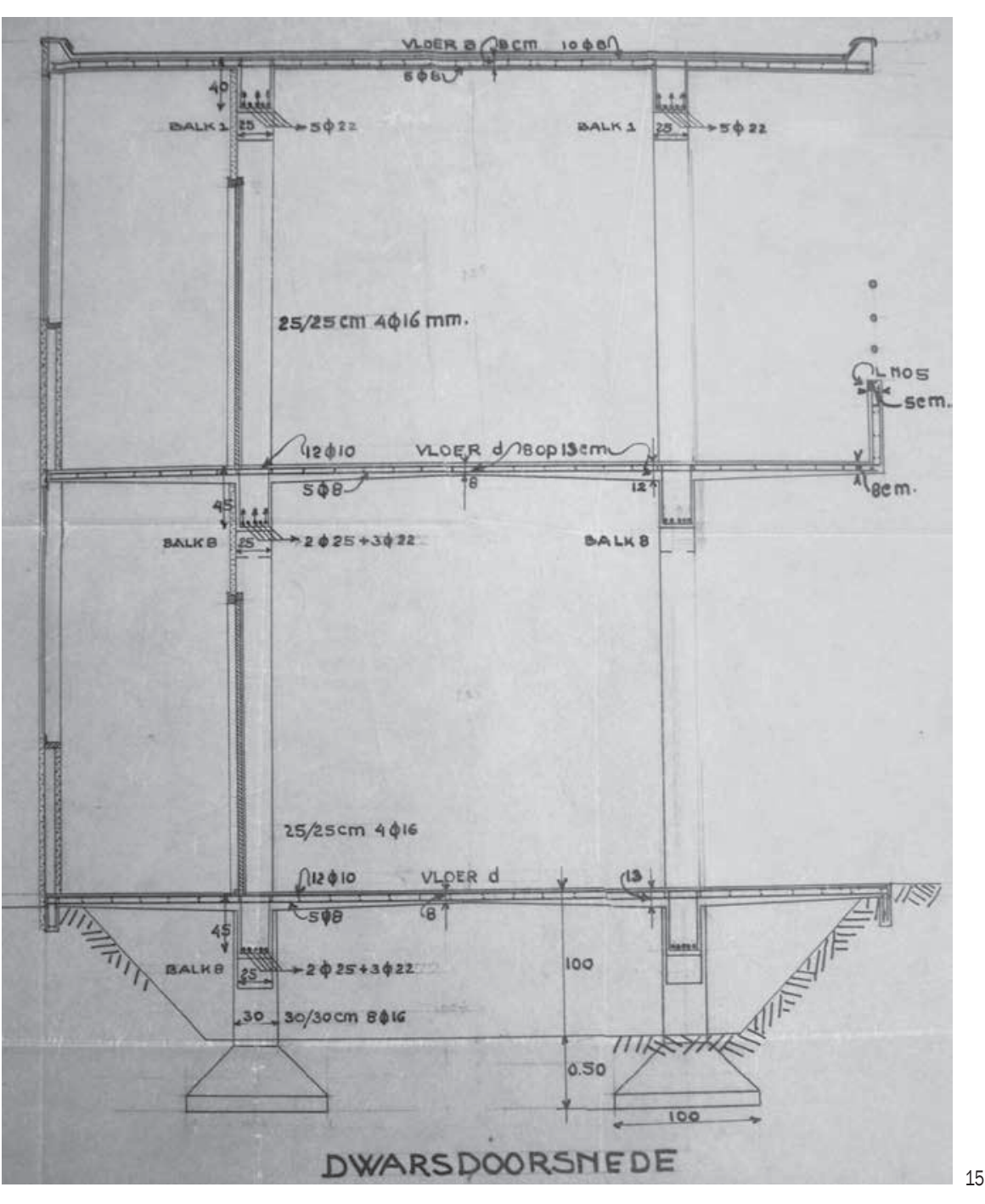

15. Zonnestraal. Section through pavilion. In situ cantilevering beams and fllor slabs, based on a T-beam prefab system, patent of Bijvoet, Duiker and Wiebenga; obtained in 1926. (Patent published by
C.A. Alberts and J.J Jelles in: Jan Duiker 1890-1935.)

\section{CONCRETE OR STEEL}

In later years Duiker would apply steel frames, but around the time of the Salesel competition he would still use concrete, as may be visible in the drawings we know ${ }^{57}$. We have tried to analyse the whole structure, but this seems rather the published copies of these). The rectangular part may give us a clue. Duiker seems to have been excited by the patent he had obtained in 1926 with Bernard Bijvoet and Jan Gerko Wiebenga for prefabricated reinforced and Jan Gerko Wiebenga for prefabricated reinforced and a slab (figure 15).
This system the three elaborated in what we see in the main complex of the Sanatoria Zonnestraal, most clearly the pavilions. an equilibrated system of two (or more) T-beams on columns, poured in situ. It is not difficult to see that this has been applied in the substructure of the rectangular part of the Salesel building. But how would Duiker use it in the circular (pentagonal) part of it. Was at all applicable? While we can imagine it in the three additions (the rectangular part, the stairs- and lift volume and to a certain degree where the dance floor and the the two zones in between
Here begins to falter our understanding of the structure with its impressive cantilevers of beams and slabs. Also because in the upper fleors Diker in and slabs. both parts a system of load bearing separtions beteen the rooms, at any rate in the circular part not coinciding with the main flor stuclure. For the circular part we can compare with the aleady mentioned nurses' house at Zonnestrat is it possible that Duiker thought of the floors and walls forming one stiff who placed on a set the round house at Zonnestrat in the upper floors and the Open Air School in Amsterdam in the substucture including the minn flor (whth the 'Gästeraun', the centra the pentagon as we draw it: a T-beam in a roundabou sides? Whatever the case, one must take into accoun what Duiker designed before, as well as what he drew afterwards. Unless the lacking drawings (the other floos and sections) turn up one sunny day, little else I

PROBLEMS

One may want to compare Duiker's solution with (what we know about) Schütte-Lihotsky's entry. Her's seems more modest in plan and spatial composition, but ves us some understanding of the different functions in the complex such as the covered car parking, which in Duiker's design we must imagine being placed in the (unknown) lower floor, probably in the triangular part between the street and the river on the eastern side of the it's roof forming a large terrace with a row of 'coiffé' linden trees ${ }^{58}$. What to say about materials, colours, details, about functions like the breakfast and dining rooms, what about the conducts (see for instance the toilets on the guestroom floors), there are many questions left, occasioned by the lack of documents and descriptions, though comparison with the realised works of course can help to imagine several aspects, such as the colours: "Duiker" blue, white, some pure yellow, aluminum paint on steel elements, black. upper pats as an integrat box like concrete stucture of of columns a d beams? Would this be a combination of hall)? Or should we see the stucture of the lower part of about the main structure.

A GRID

As I wrote: in the drawings that we know there are no measures, there is only one section, and some floor plan the explicit line in the small situralon drawng published by Van Loghem, which is runing through the centre points of the pentagon and the smal circes and parlile to the eastem borderine, is somewhat mislealing. We should look at the sitution and the plan in such way that the western limit lies horizontal as Van Loghem did with the axonometry Then we see the penenon, though very present by it's form, becoming less dominent in plan. The mathematical consequence of the form of the site, not a preconceived desired centralised space form.

The grid, that I introduce, gives more attention to the Thang gid the have to be careful with our conclusions because of the bad quality of the available drawings in the publications, that several parts fit in this grid of (aproximately) $15 \times 15$ meters and subdivisions. The rcctangle includes the long north-south wall of the large triangular part of the basement the same line goes right through the centre of the pentagon. Also does the east-west centre line of the whole rectangular bloc. This point was determined as the functional pivot centre of the complex Yes, but there is more. Duiker managed in this way to have another proportionally related grid following the eastem boundary! Now eventhing incluing the different circles turn out to be defined by the grid and the proportion 1:3. $\sqrt{ } 10$, consequence of the inclination of the border ines.

I guess that Duiker, after noting the angle between both sides being $18^{\circ}$, which led him to the pentagon, began to draw a grid parallel to the western boundary. Such a grid we see on some of the drawings for the League of Nations complex for instance. The basic measure of the grid as we deducted it may not be $100 \%$ precise, but the pivot point seems to have been defined by the grid. This is how far I could come in tracing the design route that Duiker choose. I leave it to the reader to study the drawings in this article and see what (s)he can add or

58. The black belts on either side of the beach 


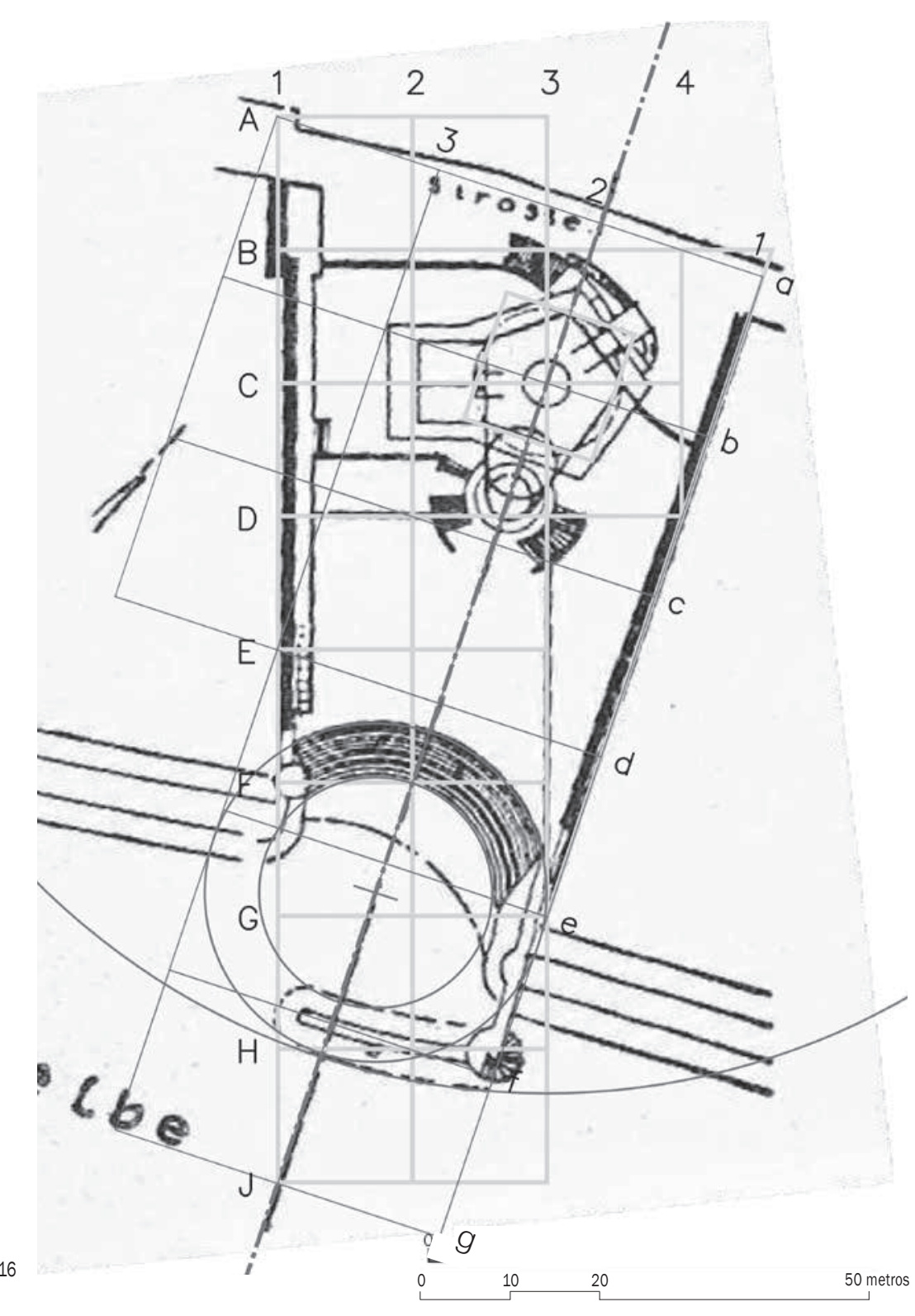

16. Multi layer drawing of Duiker's solution. Attempt portion between the smaller and the larger module is $3: 10$. This proportion comes directly from the relative inclination of the sides of the plot, and leads to the pentagon. NB As sald hetheren, had lo use the the analyses led to surprising results.

\section{References}

Aussiger Tagblatt, 22 January 1930, nr. 18, p. 3

Bak, Peter and Molema, an: Duker bouwkundis infenieur. Rotterdm. Stichting Bouw: 1982.

Hofman, Arthur: Herinneringen aan Jan Duiker. Lelystad/Rotterdam: MEDITekst 1990.

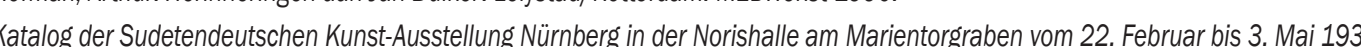
Loghem, J. B. van: Bouwen / Bauen / Bâtir/ Building Holland. Amsterdam: Kosmos 1932

Meurs, Paul and van Thoor, Marie-Thérèse (eds.): Zonnestraal Sanatorium. The History and Restoration of a Modern Monument, Rotterdam:

Molema, Jan: Jan Duiker, works and projects (preface by Kenneth Frampton), Barcelona: Gustavo Gili, 1991

Molema, Jan: "Maison de Verre / Zonnestraal. Un relato de dos edificios". En Cuadernos de Notas, número 14, Madrid, Summer 2013, pp. 98-132

Molema, Jan: Ir. J. Duiker (Serie Architectuur). Rotterdam: Uitgeverij 010, 1989.

Noever, Petr: J.D

Plischke, Ennst A.: Ein Leben mit Architektur, Wien: Locker,1989.

Robertson, Howard: Modern Architectural Design, Westminster, 1932

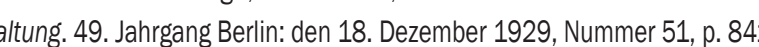

Zentrallblatt der Bauverwaltung, 50. Jahrgang. Berlin: den 5. Februar 1930 Nummer 5, p. 123.

Citations from letters by Biivoet and his wife in Hendrik Andriessen archive (153/C). Nederlands Muziekinstituut, Den Haag (The Hague)

Jan Molema Prof. Dr. Ir. Ing. Investigador jubilado en la Facultad de Arquitectura de la TU de Delft. Paises Bajos. Miembro de la Rea

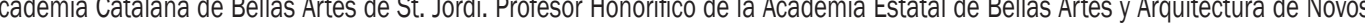
birsk, Siberia. Profesor invitado por la Universidad de Gestant de Diseño, Xalapa, Vera Cruz. Vicepresidente para Relaciones Intermacionales de STAG, Fundación Analisisis de Edificioios. Co-tundador de EAHN, European Architectural History Network. Autor de varios libros, artículos y exposiciones en Neerlandes, Inglés, Francés, Aleman, Espanon, Hungaro, Ruso, Finlandees y Japonés sobre una variedad de Bazel, la Escuela de Ámsterdam, De Groep de Delft, Antonio Gaudíy Cornet, Josep Jujol, Enric Sagnier y Bruce Gooff. 


\section{Autor imagen y fuente bibliográfica de procedencia}

Información facilitada por los autores de los artículos: página 17, 1 y 2 (Loghem, J. B. van: Bouwen / Bauen / Bâtir / Building Holland. Amsterdam: Kosmos 1932); página 18, 3 (Wiebenga archive (69-70), NAi, Rotterdam); página 20, 4 (Jan Molema), página 21, 5 (http://www.spotzi.com); página 22, 6 (Loghem, J. B. van: Bouwen / Bauen / Bâtir / Building Holland. Amsterdam: Kosmos 1932; Schütte-Lyhotski Archiv, Universität für angewannte Kunst, Vienna over a cadastral drawing on the internet: http://nah.cuzk.cz. Composed by Peter Bak and Jan Molema); página 23, 7 (Loghem, J. B. van: Bouwen / Bauen / Bâtir / Building Holland. Amsterdam: Kosmos 1932); página 24, 8 (Private collection Jan Molema), 9 (Jan Molema), 10 (Duiker Archive, NAi, Rotterdam); página 25, 11 (Van Loghem Bouwen / Bauen / Bâtir / Building Holland. Amsterdam: Kosmos 1932; C.A. Alberts and E.J. Jelles, Duiker 1890-1935, Forum, Amsterdam 1972); página 26, 12 ( Photo by courtesy of Arie den Dikken), 13 (Private collection Jan Molema); página 27, 14 ( Loghem, J. B. van: Bouwen / Bauen / Bâtir / Building Holland. Amsterdam: Kosmos 1932); página 28, 15 (Section from drawing in Duiker Archive, NAi Rotterdam); página 30, 16 (Multi-layer drawing on the basis of Duiker's site plan in Van Loghem Bouwen / Bauen / Bâtir / Building Holland. Amsterdam: Kosmos 1932. Composed by Jan Molema and Peter Bak); página 35, 1 y 2 (Francisco González de Canales); página 38, 3 y 4; página 40, 5; página 41, 6 (izda) (Koolhaas, Rem y Mau, Bruce: S, M, L, XL, Nueva York: The Monacelli Press, 1994), 6 (drcha) (Francisco González de Canales); página 41, 7; página 43, 8 y 9; página 44, 10 y 11; (Koolhaas, Rem y Mau, Bruce: S, M, L, XL, Nueva York: The Monacelli Press, 1994); página 49, 1 (Le Corbusier. En Boesiger, Willy. (Ed.): Le Corbusier Oeuvre complète. Volumen 1. 1910-29. 15a ed. Basilea: Birkhäuser Publishers - París: Fondation Le Corbusier, 1999. p. 189) ; página 51, 2 (Le Corbusier: Dibujo original del autor. FLC 10910. Fundación Le Corbusier. París, 1931), 3 (Le Corbusier: Fotografía del archivo de la FLC. FLC L2-4-41. Fundación Le Corbusier. París, s/f.); ; página 52, 4 (Le Corbusier. En Boesiger, Willy. (Ed.): Le Corbusier Oeuvre complète. Volumen 4. 1938-4. $11^{\mathrm{a}}$ ed. Basilea: Birkhäuser Publishers - París: Fondation Le Corbusier, 1999. p. 139) ; página 53, 5 (Le Corbusier: Dibujo original del autor. FLC 19238. Fundación Le Corbusier. París, 1936); página 54, 6 (Le Corbusier. EnBoesiger, Willy. (Ed.): Le Corbusier Oeuvre complète. Volumen 5. 1946-52. 11ª ed. Basilea: Birkhäuser Publishers París: Fondation Le Corbusier, 1999. p. 37) ; página 55, 7 (Le Corbusier: Dibujo original del autor. FLC 32294. Fundación Le Corbusier. París, 1951), 8 (Le Corbusier: Dibujo original del autor. FLC 2892. Fundación Le Corbusier. París, 1951), 9 (Le Corbusier. En Boesiger, Willy. (Ed.): Le Corbusier Oeuvre complète. Volumen 5. 1946-52. 11ª ed. Basilea: Birkhäuser Publishers - París: Fondation Le Corbusier, 1999. p. 121) ; página 56, 10 (Le Corbusier. En Petit, Jean. (Ed.): Un couvent de Le Corbusier. París: Éditions de Minuit, 1961. p. 112); página 58, 11 (Le Corbusier. EnBoesiger, Willy. (Ed.): Le Corbusier Oeuvre complète. Volumen 7. 1957-65. $7^{a}$ ed. Basilea: Birkhäuser Publishers - París: Fondation Le Corbusier, 1999. p. 33), 12 (Le Corbusier: Dibujo original del autor. FLC 31197. Fundación Le Corbusier. París, 1960), 13 (Le Corbusier: Dibujo original del autor. FLC 11644. Fundación Le Corbusier. París, 1963); página 60, 14 (Le Corbusier: Dibujo original del autor. FLC 28450. Fundación Le Corbusier. París, 1963), 15 (Le Corbusier: Dibujo original del autor. FLC 28460. Fundación Le Corbusier. París, 1963), 16 (Le Corbusier: A propósito del urbanismo. Barcelona: Editorial Poseidón, 1980. p. 144); página 63, 1 (From the archive of The Metropolitan Museum of Art, New York); página 64,2 (Courtesy of the digital archive of architectural images archINFORM), 3 y página 66, 4 (Wolfe, Ross: The Charnel-House. [en línea] New York. Disponible en www.thecharnelhouse.org); página 68, 5 (From the archive of the DEUTSCHES ARCHITEKTURMUSEUM), 6 (composed image, using different PROUNS of Lissintzky from www.wikipaintings.org); página 70, 7 (Composed image, using two drawing from the digital archive of architectural images archINFORM), 8 (From the permanent Collection of the Museo Nacional Centro de Arte Reina Sofía); página 74, 9 (Render of the project CAl Periféricos of the Empresa de Desarrollo Urbano de Medellín, EDU); página 78, 1 (El Croquis n.53, OMA/Rem Koolhaas, 1987-1993. Madrid: editorial El croquis, 1992, p. 167), 2 (Faucherau, Serge: Malévich, Barcelona: Ediciones Polígrafa, 1992, p. 143, figura 37), 3 (Aureli, Pier Vittorio: The Possibility of an absolute architecture. Cambridge: The MIT Press, 2011, p. 179); página 81, 4 (Gargiani, Roberto: Rem Koolhaas / OMA, the Construction of Maravilles. Lausanne: EPFL Press, 2008, p. 26 ), 5 (El Croquis n.53, OMA/Rem Koolhaas, 19871993. Madrid: editorial El croquis 1992, p. 169); página 82, 6 (El Croquis n.53, OMA/Rem Koolhaas, 1987-1993. Madrid: editorial El croquis 1992, p. 178), 7 (El Croquis n.53, OMA/Rem Koolhaas, 1987-1993. Madrid: editorial El croquis 1992, p. 173), 8 (El Croquis n.53, OMA/Rem Koolhaas, 1987-1993. Madrid: editorial El croquis 1992, p. 85), 9 (Aureli, Pier Vittorio: The Possibility of an absolute architecture. Cambridge: The MIT Press, 2011, p. 207); página 84, 10 (Venturi, Robert: Complexity and Contradicction in Architecture. New York: The Museum of Modern Art, 1966. p. 74), 11 ( AV Monografías 51-52, Enero-Abril 1995, p. 172), 12 (Arquitectura Viva n. 39, Noviembre-Diciembre 1994, p.43); página 86, 13 y 14 (OMA; Koolhaas, Rem; Mau, Bruce: SMLXL. Nueva York: The Monacelli Press, 1995. pp. 810-811); página 90, 1 (Courtesy of The MIT Press, from Grant Hildebrand, Designing for Industry: The Architecture of Albert Kahn. p.46), 2 (From the Collections of The Henry Ford); página 92, 3 (Nelson, George: Industrial Architecture of Albert Kahn, Inc. New York: Architectural Book Publishing Company, Inc, 1939, p.85. Foto: Hedrich-Blessing); página 93, 4 (Goldsmith, Myron: The Tall Building: the Effects of Scale, IIT, Chicago, 1953 (Tesis doctoral no publicada, revisada en. 1977 y 1986). [Versión consultada en: Goldmith, Myron y Werner Blaser (ed), Buildings and Concepts. New York: Rizzoli International Publications, 1987. pp.8-22.], p. 15), 5 (Goldsmith, M., op. cit. p. 17); página 94, 6 y página 95, 7 (Silvia Colmenares Vilata); página 96, 8 (Achilles, Rolf; Kevin Harrington and Charlotte Myhrum (ed.) Mies van der Rohe, architect as educator. Catalogue for the exhibition, 6 June through 12 July 1986 . Mies van der Rohe Centennial Project, IIT. Chicago: University of Chicago Press, 1986. pp.126 // Nelson, G. Op. cit. p. 38); página 97, 9 (Carter, Peter: Mies van der Rohe at Work. New York: Praeger, 1974. [Ed. Consultada: London: Phaidon, 1999, p. 8); página 98, 10 (Silvia Colmenares Vilata); página 99, 11 (Hvattum, Mari; Hermansen Cordua, Christian (eds.) Tracing Modernity: Manifestations of the Modern in Architecture and the City. London: Routledge, 2004. p. 126), 12 (Wesemael, Pieter van. Architecture of Instruction and Delight: A Socio-Historical Analysis of World Exhibitions As a Didactic Phenomenon (1798-1851-1970).Rotterdam: Uitgeverij 010, 2001. p. 170. (Manipulada)); página 100, 13 (Cedric Price fonds. Collection Centre Canadien d'Architecture/ Canadian Centre for Architecture, Montréal), 14 (Cedric Price fonds. Collection Centre Canadien d'Architecture/ Canadian Centre for Architecture, Montréal); página 101, 15 (Silvia Colmenares Vilata); página 106, 1, 2 y 3; página 108, 4 y 5 (Luis Palacios Labrador, 2011); página 110, 6 (Dibujo Luis Palacios Labrador, 2011. Fotografía: Strauven, Francis: Aldo Van Eyck. The Shape of Relativity. Amsterdam: Architectura \& Natura, 1998, pp. 375); página 113, 7 (Strauven, Francis: Aldo Van Eyck. The Shape of Relativity. Amsterdam: Architectura \& Natura, 1998, pp. 378), 8 (Strauven, Francis: Aldo Van Eyck. The Shape of Relativity. Amsterdam: Architectura \& Natura, 1998, p. 402); página 114, 9 (Risselada, Max; Van den Heuvel, Dirk: Team 10, 1953-81, in search of a Utopia of the present. Rotterdam: Nai Publishers, 2005, p. 117), 10 (Aldo van Eyck. The Web and the Labyrinth. En Lotus International. V.11. 1976); página 115, 11 (Sarkis, Hashim: Case: Le Corbusier's Venice Hospital and the Mat Building Revival. Munich: Prestel Verlag, 2001, p. 41); página 120, 1 (Antonio Millán Gómez, Marisol Jiménez, Julio Alan Latre y Víctor Díaz-Asensio García); página 123, 2 (Latre Cabrera, Julio Alan y Jiménez Rivera, Marisol); página 124, 3 (3.a. Busquets, Joan: El centro Histórico de Barcelona, un Pasado con futuro. Barcelona: Ajuntament de Barcelona, Foment Ciutat Vella; Universitat Politècnica de Catalunya, 2003; 3.b www.europeana.eu/portal/record/91932/CA529705B53B599FDD3C9A1ED7D5130497F5D000.html), 4 (Antonio Millán Gómez, Marisol Jiménez, Julio Alan Latre y Víctor Díaz-Asensio García); página 126, 5 (Latre Cabrera, Julio Alan y Jiménez Rivera, Marisol); página 128, 6 (llustre Municipalidad de Santiago); página 129, 7 (Archivo Visual de Santiago (www.archivovisual.cl) e llustre Municipalidad de Santiago / Santiago Centro. pp. 24-25); página 130, 8 (Lazo Mella, Felipe ; Millán Gómez, Antonio); página 131, 9 (Atlas del Proyecto de saneamiento del subsuelo de BarceIona. Lamina 3. Archivo Histórico de la Ciudad de Barcelona) 